Dunamis: Jurnal Teologi dan Pendidikan Kristiani

Volume 4, Nomor 2 (April 2020)

ISSN 2541-3937 (print), 2541-3945 (online)

http://www.sttintheos.ac.id/e-journal/index.php/dunamis

DOI: 10.30648/dun.v4i2.237

Submitted: 14 November 2019

Accepted: 2 Maret 2020

Published: 16 Maret 2020

\title{
Evaluasi Seratus Hari Periode Kedua Pemerintahan Presiden Joko Widodo Melalui Peristiwa Penobatan Saul sebagai Raja
}

\author{
Jozef M.N. Hehanussa \\ Fakultas Teologi, Universitas Kristen Duta Wacana \\ jozef_mnh@staff.ukdw.ac.id
}

\begin{abstract}
Saul as the first king of Israel is often regarded as a king who was rejected by God. According to 1 Samuel 13, he had acted against the will of God as Samuel had reminded. However, from a different perspective can be found the good values of King Saul's leadership. The author used the narrative interpretation method of 1 Samuel 10-11 in order to explore the positive values of King Saul's leadership which were then used as an evaluation for 100 days of the second period of President Joko Widodo's reign. The result is President Joko Widodo's efforts in building peace should be appreciated, but in upholding justice and human rights leave an unsatisfactory record.
\end{abstract}

Keywords: King Saul; Israel; leadership; peace; Joko Widodo

\begin{abstract}
Abstrak
Saul sebagai raja pertama Israel sering dianggap sebagai raja yang ditolak oleh Allah. Menurut 1 Samuel 13, dia telah bertindak melawan kehendak Tuhan yang telah diingatkan oleh Samuel. Namun demikian, dari perspektif yang berbeda dapat ditemukan nilai-nilai kepemimpinan yang baik dari Raja Saul. Penulis menggunakan metode tafsir naratif terhadap 1 Samuel 10-11 dalam rangka menggali nilai-nilai positif dari kepemimpinan Raja Saul tersebut yang kemudian digunakan sebagai evaluasi bagi 100 hari periode kedua pemerintahan Presiden Joko Widodo. Hasilnya adalah dalam hal upaya Presiden Joko Widodo untuk menciptakan damai sejahtera patut diapresiasi, namun dalam hal tanggung jawab untuk menegakkan keadilan dan HAM masih menjadi catatan yang belum memuaskan.
\end{abstract}

Kata Kunci: Raja Saul; Israel; kepemimpinan; damai; Joko Widodo 


\section{PENDAHULUAN}

Berbicara tentang kepemimpinan Israel, Daud dan juga Salomo selalu menjadi figur utama dalam keteladanan sebagai raja, di mana orang bisa belajar dari kejayaannya maupun kejatuhannya. Sebagai raja Israel pertama, ada kesan bahwa Saul menjadi figur yang kurang begitu penting dalam pembahasan tentang kepemimpinan di Israel. David M. Gunn mengatakan bahwa tradisi Kristen kurang memberikan penghargaan kepada Saul dibandingkan dengan tradisi Yahudi yang masih lebih bersimpati kepada Saul. ${ }^{1}$ Ada kesan bahwa penulis 1 Samuel menggiring para pembacanya kepada sebuah sikap "anti" Saul berkaitan dengan tindakannya mempersembahkan korban bakaran, yang seharusnya itu merupakan tugas seorang imam (Samuel), bukan raja (1 Sam. 13:8-14). Kisah penolakan Saul sebagai raja akibat kesalahan yang dilakukannya sebenarnya mengingatkan pembaca kepada "penghentian" tanggung jawab kepemimpinan Musa karena dianggap telah melakukan apa yang berlawanan dengan perintah Tuhan (bd. Bil. 20:2-12; Ul. 32:5052). Jika pembaca tidak hati-hati dalam membaca kisah penolakan pemimpin ini dihubungkan dengan tindakannya yang men-

1 David M. Gunn, Fate of King Saul: An Interpretation of a Biblical Story (Sheffield: JSOT Press, 1989), 23-24.

${ }^{2}$ Lih. Tomoo Ishida, History and Historical Writing in Ancient Israel: Studies in Biblical Historiography jadi alasan penolakannya, pembaca bisa beranggapan bahwa kesalahan Saul (dan juga Musa) derajatnya lebih parah dibandingkan dengan kesalahan Daud terhadap Uria dan Batsyeba (2 Sam. 11:1-27). Karena itu Saul langsung ditolak sebagai raja, sementara Daud karena pertobatannya dia masih tetap dipercayakan sebagai seorang raja. Padahal sama seperti Daud, Saul juga menyadari dan menyesali dosanya serta memohon pengampunan (1 Sam. 15: 24-31). Perlu menjadi catatan bahwa narasi kepemimpinan dalam Israel tidak bisa dilepaskan dari konsep suksesi di dunia politik kekuasaan dan karena itu selalu ada tokoh tertentu yang menjadi figur penting dalam suksesi kepemimpinan dan ada tokoh lain yang akan dianggap lebih kurang derajat kepemimpinannya dibandingkan dengan pemimpin yang lain. Dan dalam sejarah Israel konsep suksesi itu lebih berpusat pada keluarga atau dinasti Daud, bukan Saul. ${ }^{2}$ Dengan begitu pembaca bisa dengan mudah mengerti mengapa penulis kitab 1 Samuel dengan cepat menghubungkan penolakan atau penghentian Saul sebagai raja dengan kesalahannya melawan perintah Allah.

(Leiden: Brill, 1999); Jacob L. Wright, David, King of Israel, and Caleb in Biblical Memory (New York: Cambridge University Press, 2014). 
Tulisan ini bertujuan menggali keteladanan Saul sebagai raja Israel yang diurapi Allah melalui Samuel. Perjanjian Lama tidak hanya sekadar menyajikan Saul sebagai raja "figuran" sebelum tibanya masa Daud. Kisah raja-raja Israel juga telah mencatat Saul sebagai raja pertama Israel bukan hanya telah berhasil memimpin Israel menghadapi musuh-musuhnya melainkan juga merupakan raja yang dipilih atau dikehendaki oleh rakyat. Meminjam bahasa politik saat ini Saul adalah raja yang dipilih melalui sebuah proses demokratis, meskipun 1 Samuel 10 menyajikan narasi yang memberi kesan bahwa Tuhan sendiri telah lebih dahulu memilih dan mengurapi Saul sebagai raja melalui Samuel sebelum pilihan raja "ditawarkan" kepada umat Israel (1 Sam. 10:17-26).

Nilai-nilai kepemimpinan Saul yang digali dari pemahaman atas teks 1 Samuel 10-11 selanjutnya akan dipakai untuk menilai kepemimpinan politik di Indonesia khususnya kepemimpinan Presiden Joko Widodo, atau yang sering dikenal dengan nama Jokowi, setelah 100 hari dilantik sebagai Presiden untuk kedua kalinya. Upaya menarik pesan teks ini ke dalam konteks kehidupan politik pemerintahan di Indonesia karena nilai kepemimpinan Saul

\footnotetext{
${ }^{3}$ Geoffrey P. Miller, The Ways of a King: Legal and Political Ideas in the Bible (Vandenhoeck \& Ruprecht, 2011), 226-236.
}

juga berhubungan dengan tanggung jawab Saul sebagai seorang pemimpin politis. Artinya bahwa tanggung jawab kepemimpinan Saul tidak hanya berhubungan dengan masalah-masalah religius saja, tetapi juga kepemimpinan masyarakat atau dengan kata lain juga bersifat politis. ${ }^{3}$ Untuk itu nilai-nilai kepemimpinan yang dimunculkan dari Saul dapat menjadi poin penting dalam menilai dan melihat pemerintahan di Indonesia pasca 100 hari pelantikan Presiden Joko Widodo.

\section{METODE PENELITIAN}

Tulisan ini menggunakan metode penelitian literer atau studi pustaka. Permasalahan yang ada dikaji menggunakan pustaka-pustaka pendukung terkait dan juga hasil-hasil studi yang berkaitan dengan pokok bahasan. Pustaka ini baik dalam bentuk buku maupun jurnal. Metode pembacaan dan penafsiran teks akan menggunakan pendekatan naratif ${ }^{4}$ dan sosio-historis. Sedangkan pembahasan pokok-pokok pikiran yang ada akan disajikan dengan menggunakan metode deskriptif-analitis.

Tahapan pertama adalah menafsirkan peristiwa-peristiwa di sekitar penoba$\tan$ Saul sebagai raja dalam 1 Samuel 10-11 sesuai dengan makna naratifnya. Penafsiran

\footnotetext{
${ }^{4}$ Lih. P. A. Didi Tarmedi, "Analisis Naratif: Sebuah Metode Kristiani Hermeneutika Kitab Suci," MELINTAS 29, no. 3 (2013): 331-360.
} 
ini bertujuan untuk menemukan pesan yang terkandung dalam teks. Pendekatan sosiohistoris dipakai untuk melihat konteks sosial masyarakat di sekitar teks secara holistik. Pendekatan ini penting karena hasil pemaknaannya membantu melihat konteks kepemimpinan di Indonesia untuk saat ini, khususnya kepemimpinan Presiden Joko Widodo. Tahapan kedua adalah teks yang telah ditafsir dan pesan teks dihubungkan dengan konteks Indonesia saat ini, khususnya berkaitan dengan isu kepemimpinan. Tahapan kedua ini terkait dengan tahapan ketiga, yaitu menerjemahkan pesan teks ke dalam konteks kepemimpinan di Indonesia. Dalam tahapan ini nilai-nilai yang ada dipakai untuk mengkritisi 100 hari kepemimpinan Presiden Joko Widodo.

\section{HASIL DAN PEMBAHASAN}

\section{Pemimpin yang Rendah Hati}

Suku Benyamin merupakan suku terkecil di antara 12 suku Israel. Suku tersebut bahkan pernah terpisah dari kesebelas suku Israel lainnya karena peristiwa di Gibea (Hak. 19). Studi yang dilakukan Daniel Fleming juga memperlihatkan bahwa Benyamin kurang mendapat posisi penting dalam teks Perjanjian Lama. ${ }^{5}$ Bahkan

\footnotetext{
${ }^{5}$ Daniel Fleming, The Legacy of Israel in Judah's Bible: History, Politics, and the Reinscribing of Tradition (New York: Cambridge University Press, 2012), 144-161.
}

ketika Tuhan menghancurkan kerajaan Israel Utara, kitab 2 Raja-raja mencatat bahwa dari semua suku di Israel tidak ada lagi yang tertinggal kecuali suku Yehuda (2 Raj. 17:18). Jika penghancuran ini benarbenar dimaksudkan sebagai penghancuran kerajaan Israel Utara maka seharusnya yang masih tertinggal adalah suku Yehuda dan Benyamin, karena Benyamin bergabung dengan kerajaan Yehuda. Pernyataan penulis kitab 2 Raja-raja ini memperlihatkan bahwa Benyamin bukanlah suku yang penting di antara 12 suku Israel. Tetapi ada juga alasan lain adalah karena suku ini bahkan kadang dikaitkan dengan Yehuda atau Efraim. ${ }^{6}$ Catatan-catatan ini menolong pembaca untuk memahami kenapa Saul merasa tidak yakin terhadap pernyataan Samuel bahwa dia memenuhi kriteria sebagai raja sebagaimana yang di harapkan oleh Israel. Saul menyadari bahwa dia sendiri berasal dari suku yang terkecil dari bani Israel dan yang “dikucilkan" dari sukusuku Israel lainnya. Inilah salah satu nilai penting yang diberi Saul, yaitu sikap kerendahan hati seorang pemimpin. Karena sikap rendah hati ini dia tidak merasa tersanjung ketika dikatakan oleh Samuel bahwa dia dipilih Tuhan untuk menjadi raja

\footnotetext{
6 Ibid., 149; Philip R. Davies, "Saul, Hero Dan Villain," in Remembering Biblical Figures in the Late Persian and Early Hellenistic Periods, ed. Diana V. Edelman and Ehud Ben Zvi (Oxford: Oxford University Press, 2013), 135.
} 
atas Israel. Saul lebih memperlihatkan ketidaklayakannya, bukan perasaan mampu menjadi seorang raja.

Pola pikir Saul ini memperlihatkan pola pikir yang juga menonjol di zaman ini bahwa seorang pemimpin harus datang dari kelompok yang menonjol atau berpengaruh. Dalam pemikiran mayoritas masyarakat pemimpin biasanya datang dari kelompok mayoritas atau yang memiliki pengaruh besar, bukan kelompok minoritas atau yang kurang berpengaruh. Pemimpin juga bukan orang yang masih muda seperti Saul. Seorang pemimpin biasanya haruslah seorang yang sudah cukup usianya atau tua karena akan lebih bijaksana. ${ }^{7}$ Tetapi pilihan Tuhan atas Saul memunculkan setidaknya dua penafsiran. Pertama, kisah ini memperlihatkan sebuah "pengecualian" dari pola pikir yang menonjol terkait dengan keberadaan suku Yehuda yang mendapat tempat penting dalam suksesi raja-raja Israel, khususnya kerajaan Yehuda (Israel Selatan). Pengecualian ini memiliki kesejajaran dengan suksesi raja-raja Israel Utara yang mengedepankan keturunan Yusuf, karena Yerobeam, raja pertama kerajaan Israel Utara berasal dari suku Yusuf (Efraim). Dan bukan kesengajaan jika Yusuf dan Benyamin merupakan dua saudara sekandung dari satu ibu, Rachel. Jadi

\footnotetext{
7 Robert Setio, "Penguasa, Tuhan, Dan Rakyat:
} Membaca Apokalips Daniel 7 Sebagai Subversi," dari keturunan Benyamin muncul raja pertama Israel yang dipilih oleh Tuhan dan dari suku Yusuf muncul raja pertama Israel Utara sesuai dengan nubuat nabi Ahia (1 Raj. 11:26-40). Kedua, Tuhan yang pernah mengizinkan kesebelas suku Israel melawan Benyamin karena peristiwa Gibea, bahkan membiarkan kesebelas suku ini untuk mengangkat perjanjian "mengisolasi" suku Benyamin, justru memilih raja pertama Israel dari suku Benyamin. Itu artinya bahwa di satu sisi perizinan Tuhan kepada kesebelas suku Israel untuk melawan dan mengisolasi suku Benyamin tidak berarti bahwa Tuhan berada di pihak kesebelas suku Israel. Di sisi lain, itu juga berarti bahwa Tuhan tetap melihat Benyamin sebagai satu kesatuan bagian penting dari 12 suku Israel.

Dipilih dari suku yang minoritas, yang cenderung dianggap tidak penting, tidak membuat Saul menjadi berbangga diri. Dia bahkan tidak menceritakan kepada siapa-siapa perihal pengurapannya sebagai raja oleh Samuel. Dalam 1 Samuel 10:16 ditulis: "Tetapi perihal menjadi raja yang telah dikatakan Samuel kepadanya, tidak diceritakan kepadanya." Teks ini berhubungan dengan permintaan paman Saul agar Saul menceritakan apa yang telah dikatakan Samuel kepadanya, ketika Saul dan salah Filsafat Keilahian 4, no. 2 (October 16, 2019): 224. 
seorang bujangnya mencari Samuel, si pelihat, untuk mendapat informasi tentang keberadaan keledai-keledainya yang hilang. Bahkan dalam bagian selanjutnya (1 Sam. 10:21-22) dikatakan bahwa Saul yang telah diurapi Samuel sebagai raja tidak tampil di tengah-tengah umat Israel yang sedang memilih raja barunya. Saul bahkan menyembunyikan dirinya dari saudara-saudara sebangsanya. Sikap dan tindakan Saul ini menurut saya lebih memperlihatkan sebuah sikap rendah hati Saul. Karena sadar bahwa dia berasal dari suku yang kurang diperhitungkan maka pengurapan dirinya sebagai raja secara 'diam-diam' oleh Samuel tidak digembar-gemborkannya. Saul tidak terburu-buru untuk melegitimasi pilihan Allah atas dirinya sebagai raja melainkan menunggu persetujuan dari saudara-saudara dari suku-suku yang lain. Saul mungkin menyadari adanya ketegangan di antara sukunya dan suku-suku lain dan karena itu dia harus bisa menahan diri untuk tidak segera menyatakan dirinya sebagai raja atas Israel. Apalagi Samuel pun mengurapi dia sebagai raja secara diam-diam, bahkan sebelumnya meminta Saul menyuruh pergi bujangnya agar hanya ada Samuel dan Saul saja ketika Samuel menyampaikan firman Tuhan kepada Saul (1 Sam. 9:27).

Saul juga tidak mengubah pola atau gaya hidupnya, sekalipun telah mendapat persetujuan bangsa Israel untuk menjadi raja atas mereka. Dalam 1 Samuel 11:5 dikatakan bahwa sekalipun telah menjadi seorang raja Saul masih tetap melakukan tanggung jawabnya sebagai seorang peternak yang sehari-hari mengurusi ternaknya di padang sebagaimana sebelum dia ditetapkan sebagai raja. Namun ketika kepadanya diperhadapkan kepada tanggung jawabnya sebagai seorang raja, Saul langsung mengambil tindakan sebagai seorang raja (1 Sam. 11:6).

\section{Pemimpin yang Mengayomi dan Mem- bawa Damai}

Membaca ketegangan relasi antara Israel dan bangsa-bangsa di sekitarnya mengingatkan saya akan ketegangan hubungan antara kerajaan Romawi dan Persia. Kedua kerajaan ini selalu berada dalam konflik dan setiap raja atau kaisar Romawi memiliki tanggung jawab untuk menjaga Romawi dari pengaruh kekuasaan Persia. Barulah pada tahun 20 SM Kaisar Agustus berhasil memaksa Phraates IV untuk menandatangani pakta damai yang dikenal dengan nama Pax Romana. Sejak menduduki tanah perjanjian, suku-suku Israel memang harus selalu menjaga wilayah mereka dari keinginan bangsa-bangsa sekitar yang ingin merebutnya wilayah mereka. Sejak zaman para hakim Israel sering kali jatuh bangun dalam menjaga wilayah mereka. Untuk itu ketika Saul diurapi sebagai raja dia me- 
ngemban tugas yang sama. Tuhan melalui Samuel berpesan kepadanya (1 Sam. 10:1), “...engkau akan menyelamatkannya dari tangan musuh-musuh di sekitarnya." Pesan ini dapat diartikan sebagai misi utama yang diberikan Tuhan kepada Saul. Itu artinya sebagai raja Saul berkewajiban untuk lebih menghadirkan rasa aman bagi orang-orang yang dipimpinnya lebih dari pada memberikan rasa aman bagi dirinya sendiri. Dan untuk melaksanakan tugas tersebut dia didampingi oleh orang-orang gagah perkasa (1 Sam. 10:26), yaitu orang-orang yang hatinya telah digerakkan oleh Allah dan ini tentu saja dengan tujuan untuk mendukung Saul menjalankan mandat yang diberikan Tuhan kepadanya.

Allah tidak pertama-tama memberikan kepadanya keistimewaan atau apa yang menjadi haknya sebagai raja, melainkan tanggung jawab. Itu artinya bahwa kepada Saul hendak ditekankan bahwa pemimpin harus pertama-tama lebih mengedepankan tanggung jawabnya kepada orang-orang yang dipimpinnya dan bukan mengutamakan apa yang menjadi haknya. Prinsip ini seharusnya menjadi model dan perilaku para pemimpin dalam melaksanakan tugas mereka. Prinsip lain yang perlu dikedepankan ketika seorang pemimpin menjalankan tanggung jawabnya berhubungan dengan konsep "orang yang dipimpin sebagai subjek dan umat Tuhan.” Teks 1 Samuel 10:1 dengan tegas memperlihatkan bahwa sekalipun Saul diangkat sebagai raja, tetapi umat yang dipimpinnya tetaplah umat Tuhan. Penyebutan umat Tuhan mengandung arti bahwa Israel tetap menjadi miliki Tuhan dan tetap mendapat perhatian dan kasih Tuhan. Israel mengambil tempat sebagai subjek dalam setiap rencana Tuhan. Karena itu jika Tuhan mengasihi umatnya dan menempatkan mereka sebagai subjek dalam setiap karyanya, maka raja pun harus menunjukkan kasihnya kepada umat Tuhan itu dan bukan malah menyusahkan mereka dan menjadikan mereka hanya sebagai objek dari kepemimpinannya. Jika konsep “orang yang dipimpin adalah subjek dan umat Tuhan" dibangun dalam implementasi kepemimpinan saat ini, maka pemimpin akan lebih mengedepankan kebaikan hidup dari orang-orang yang dipimpinnya, bukan diri si pemimpin. Konsep "umat Tuhan" dalam konteks kepemimpinan saat ini dapat dihubungkan dengan kesadaran bahwa orang-orang yang dipimpin adalah manusiamanusia ciptaan Tuhan yang diberi dan dijamin haknya untuk hidup dalam damai dan sejahtera serta diperlakukan dengan adil, dan bahwa ada jaminan atas pemenuhan hak-hak hidup dasarnya.

Saul juga menunjukkan keteladanan dalam bentuk tidak membalas kejahatan dengan kejahatan. Keteladanan ini dapat diartikan sebagai cara Saul menunjukkan 
bahwa dia memang lebih mengutamakan rasa aman bagi orang-orang yang dipimpinnya dan menunjukkan penghargaannya kepada orang-orang yang dipimpinnya sebagai umat Tuhan. Dalam 1 Samuel 10:27 disebutkan tentang anak-anak Belial (Lembaga Alkitab Indonesia: orang-orang dursila; International Standard Version: troublemakers; New International Version: scoundrels; atau sering dihubungkan dengan Setan) yang mengatakan: "'Masakan orang ini dapat menyelamatkan kita!' Mereka menghina dia dan tidak membawa persembahan kepadanya.” Ini menunjukkan bahwa tidak semua orang mendukung pengangkatan Saul sebagai raja dan bahkan menunjukkan sikap yang tidak menyenangkan kepada Saul sebagai raja terpilih. Penulis sepertinya ingin memperhadapkan atau mempertentangkan antara anak-anak Belial yang menolak kepemimpinan Saul dengan orang-orang gagah perkasa (hayil) yang menjadi pendukung Saul. Interpretasi yang dibuat oleh Walter Brueggemann ${ }^{8}$ bahwa kata hayil mengandung implikasi sosial dan ekonomi juga menunjukkan dengan tegas perbandingan dengan anakanak Belial. Yang pertama memberi dukungan juga secara sosial ekonomi, sedangkan yang kedua tidak mau memberi

\footnotetext{
${ }^{8}$ Walter Brueggemann, First and Second Samuel (Lousville, Kentucky: Westminster John Knox Press, 2012), 81.
}

dukungan sama sekali yang ditunjukkan dengan tidak membawa persembahan kepada Saul. Dalam konteks politik kepemimpinan saat ini, anak-anak Belial ini dikategorikan sebagai kelompok oposisi atau kelompok yang menentang pemerintahan yang sah. Meskipun demikian sikap yang ditunjukkan Saul terhadap orang-orang ini memberikan keteladanan penting bagi seorang pemimpin dalam menyikapi orangorang yang menentang mereka. Pertama, dalam 1 Samuel 10:27c dikatakan: "Tetapi ia (Saul) pura-pura tuli." (King James Version: "But he held his peace."; Luther Bible: "Er aber tat, als hörte er's nicht.").

Upaya menghadirkan kehidupan damai sejahtera ini dapat dilihat melalui tindakan Saul ketika menyelamatkan Yabesh-Gilead. Tindakan Saul menyelamatkan penduduk Yabesh memperlihatkan kepeduliannya terhadap mereka yang berada dalam penindasan. Saul ingin menghadirkan rasa aman dan damai untuk Yabesh-Gilead yang ditindas oleh bangsa lain. Ini adalah tindakan Saul yang pertama sebagai seorang raja. Ini menunjukkan bahwa karena Saul adalah pemimpin masyarakat maka yang harus dia lakukan pertama-tama adalah untuk masyarakat. Dia menyelamatkan penduduk Yabesh dari 
serangan Nahas orang Amon agar mereka bisa hidup dalam damai. Zev Farber mengatakan bahwa penduduk Yabesh sedang berusaha mendapatkan seorang moshiah, Mesias, atau tokoh yang mampu menyelamatkan mereka di tengah situasi tersebut. Saul berhasil memerankan tokoh yang diharapkan Yabesh dengan menjadi t'shua, penyelamat. Kisah ini menjadi alasan Farber menyejajarkan tindakan Saul dengan tindakan Yosua menyelamatkan Gibeon (Yos. 10) yang juga mengalami situasi seperti penduduk Yabesh. ${ }^{9}$ Tindakan Saul terhadap penduduk Yabesh ini membuat dia sangat dihormati oleh orang Yabesh. Karena itu ketika orang-orang Yabesh mendengar bahwa Saul telah mati dibunuh orang Filistin, mereka berusaha untuk mendapatkan mayatnya dan memakamnya dengan baik (1 Sam. 31: 11-13).

Berhasil menyelamatkan penduduk Yabesh-Gilead tidak membuat Saul menjadi sombong. Orientasi berpikirnya selalu pada kehidupan yang aman dan damai dari seluruh rakyat yang dipimpinnya. Karena itu Saul menolak membunuh orang-orang yang menganggap remeh Saul sebagai raja. Dalam 1 Samuel 11:12, setelah Saul berhasil menyelamatkan penduduk Yabesh, ada orang-orang yang menyarankan Samuel

\footnotetext{
${ }^{9}$ Zev Farber, Images of Joshua in the Bible and Their Reception (Berlin: Walter de Gruyter $\mathrm{GmbH}$, 2016), 115-116.
}

untuk membunuh mereka yang meremehkan Saul sebagai raja. Namun Saul tidak menyetujui usul tersebut. Dia lebih menginginkan kedamaian bagi seluruh umat setelah Tuhan memberikan keselamatan kepada Israel. ${ }^{10}$ Saul mengatakan (1 Sam. 11:13), "Pada hari ini seorang pun tidak boleh dibunuh, sebab pada hari ini TUHAN telah mewujudkan keselamatan kepada Israel.” Itu artinya bagi Saul keselamatan atau pertolongan yang telah diberikan Tuhan menjadi bagian dan harus dinikmati oleh semua orang Israel tanpa terkecuali dan karena itu membunuh satu orang saja dari orang Israel berarti tidak menghargai keselamatan yang diberikan Tuhan. Dengan kata lain, jika Tuhan saja menyelamatkan dan memberikan kehidupan kepada orang Israel, bagaimana bisa di saat itu Saul mengizinkan ada orang Israel yang hidupnya harus dihilangkan. Saul ingin merangkul semua rakyat, baik yang mendukungnya maupun yang tidak mendukungnya, di bawah kepemimpinannya. Sikap Saul ini bahkan membuat dia semakin didukung oleh semua orang Israel dan kedudukannya sebagai raja semakin dikokohkan (1 Sam. $11: 15)$

\footnotetext{
${ }^{10}$ Lih. Stephen B. Chapman, 1 Samuel as Christian Scripture: A Theological Commentary (Wm. B. Eerdmans Publishing, 2016), 115-116.
} 


\section{Pemimpin yang Menentang Ketidak- adilan}

Pakar seperti David Gunn ${ }^{11}$ memberikan penghargaan pada sisi kultis Saul ketika dia diperkenalkan dalam narasi dan diurapi sebagai raja - yang tidak ditemukan pada Daud. Penonjolan sisi kultis ini merupakan bentuk simpati terhadap Saul yang kemudian "tersingkir" karena narasi politik penobatan Daud sebagai raja selanjutnya yang dimasukkan dalam narasi sebelum akhir masa kepemimpinan Saul. Tetapi penobatan Daud sebagai penerus kepemimpinan Saul sendiri tidak pernah diartikan sebagai akhir masa kepemimpinan Saul, karena Saul tetap berperan sebagai raja Israel sampai dengan matinya. Sementara bagi Blenkinsopp ${ }^{12}$ kenabian Saul dan nubuat yang diucapkan merupakan sebuah peristiwa istimewa yang melengkapi penunjukannya sebagai raja yang karismatik atas Israel. Menonjolkan penolakan Saul sebagai raja memang akan cenderung mengabaikan peran positif Saul dalam masa kepemimpinannya. Karena itu dalam sebagian besar penafsiran narasi penobatan Saul sebagai raja, narasi kenabian dan nubuat

\footnotetext{
${ }^{11}$ Gunn, Fate of King Saul; band. Mark K. George, "Yhwh's Own Heart," The Catholic Biblical Quarterly 64, no. 3 (2002): 451-453.

12 Joseph Blenkinsopp, A History of Prophecy in Israel (Lousville, Kentucky: Westminster John Knox Press, 1996), 54.

${ }^{13}$ Band. Dan Merkur, "Biblical Terrorism," in A Cry Instead of Justice: The Bible and Cultures of
}

Saul kurang mendapat pembahasan yang serius. Pembahasan ini tidak berupaya menemukan asal-usul kenabian Saul, ${ }^{13}$ namun ingin lebih menekankan keterlibatan Saul dalam nubuat bersama-sama dengan rombongan nabi.

Dalam sejarah raja-raja Israel tidak ada satu raja pun selain Saul yang mengalami kepenuhan dan bernubuat seperti nabi. Orang-orang yang melihat apa yang dilakukan Saul bahkan berpikir bahwa Saul termasuk dalam golongan nabi (1 Sam. 10:11-12). Robert Polzin mengatakan bahwa kemampuan kenabian Saul sudah terlihat pada 1 Samuel 9:5 karena apa yang dikatakannya sama seperti yang dikatakan Samuel, si pelihat (1 Sam. 10:2). ${ }^{14}$ Kisah Saul dan Samuel memang memperlihatkan hal yang tidak biasa dalam tradisi kenabian Israel. Yang pertama berkaitan dengan kemampuan Saul untuk bernubuat seperti seorang nabi. Yang kedua berkaitan dengan Samuel sebagai nabi yang mempersembahkan korban bakaran dan korban keselamatan. Peran nabi sebagai imam juga ditemukan dalam diri Elia (1 Raja. 18). Dalam kisah Saul perannya sebagai nabi dan

Violence in Psychological Perspective, ed. Dereck Daschke and D. Andrew Kille (New York: T \& T Clark, 2010), 66-68.

${ }^{14}$ Robert Polzin, Samuel and the Deuteronomist: A Literary Study of the Deuteronomic History Part Two: 1 Samuel (Bloomington \& Indianapolis: Indiana University Press, 1993), 101. 
nubuat yang diucapkannya dimungkinkan untuk terjadi karena Roh Tuhan berkuasa atasnya (1 Sam. 10:6, 10). Saul kembali mengalami pengalaman kenabian ketika dia sendiri pergi menjemput Daud di Nayot dekat Rama (1 Sam. 19:23-24). Pengalaman yang sama juga dapat ditemukan dalam diri orang-orang yang disuruh Saul untuk mengambil Daud, sebagaimana dijelaskan dalam 1 Samuel 19:20-22. Mengutip pemikiran Rabbi E. Dessler, Boruch Clinton mengatakan bahwa untuk bisa menjadi seorang raja Yahudi yang sukses tidak memimpin dengan menggunakan kemampuan dirinya maupun pedangnya, melainkan melalui mata yang diterangi oleh inspirasi ilahi, yang mana melaluinya seorang raja dapat "melihat" apa yang terjadi dalam kehidupan orang-orang yang dipimpinnya dan juga dalam kerajaannya. ${ }^{15}$ Dalam pemikiran seperti inilah nubuat Saul dapat dipahami. Sebagai raja, Saul diharapkan dapat memiliki kemampuan khusus untuk "melihat" apa yang dikehendaki Tuhan bagi orang-orang yang dipimpinnya. Karena itu Saul diberkati dengan kemampuan sebagai seorang nabi yaitu bisa bernubuat. Kemampuan ini ditandai oleh Roh Allah yang berkuasa atasnya. Itu artinya bahwa kemampuan Saul ini tidak permanen, me-

${ }^{15}$ Boruch Clinton, The Royal Prophet - And Other Thoughtful Essays on the Book of Samuel (Toronto: Marbitz Media, 2014), 30; Thomas L. Leclerc, lainkan bergantung pada keberadaan Roh Tuhan di dalam dirinya.

Pertanyaan "Apa Saul juga termasuk golongan nabi?" menurut saya bukan pertanyaan yang eksistensialis, melainkan hanya sebuah pertanyaan retoris. Teks lebih memberi penekanan pada aktivitas kenabian Saul yang dimungkinkan karena Roh Allah berkuasa atas dirinya. Roh Allah yang berkuasa atas Saul telah membuat dia menjadi manusia lain dan memiliki hati yang lain. Dia bukan hanya Saul seorang peternak yang diurapi menjadi raja, melainkan raja yang diberi karunia untuk bernubuat dan melakukan apa saja yang ditemui tangannya selama Tuhan bersamasama dengan dia. Tidak ada kejelasan tentang apa yang dinubuatkan Saul bersama dengan rombongan para nabi itu, tetapi bisa jadi Saul dan rombongan nabi tersebut bernubuat dengan menggunakan alat-alat musik yang dibawa rombongan nabi tersebut. Sudah jelas bahwa nubuat selalu berhubungan dengan menyampaikan apa yang menjadi kehendak Allah, tetapi kehendak Allah yang disampaikan dalam peristiwa di Gibea disertai dengan memuliakan Allah. Dengan demikian dalam situasi ini Saul tidak hanya menjadi seorang raja yang pada waktunya akan memimpin Israel

Introduction to the Prophets: Their Stories, Sayings and Scrolls (New Jersey: Paulist Press, 2007), 6566. 
berperang, melainkan juga raja yang diberi kuasa seperti nabi untuk bernubuat menyampaikan apa yang menjadi kehendak Tuhan dan juga memuliakan Tuhan. Terlepas dari narasi berikutnya, di mana Roh Tuhan itu kemudian meninggalkan dia, Saul bukan hanya telah diurapi sebagai raja, melainkan juga diberi kesempatan untuk berperan bak seorang nabi yang menubuatkan maksud Allah. Bahkan peran itu kemudian terulang kembali di Nayot dekat Rama (1 Sam. 19:23-24).

Kisah Saul membangun sebuah kesadaran penting bagi pemimpin, bahwa selalu ada ruang di mana seorang pemimpin tidak hanya semata-mata pimpinan (leader) tetapi juga berperan seperti seorang nabi. Peran pemimpin bak seorang nabi menyatu dengan peran kepemimpinannya. Peran bak nabi ini ditunjukkan melalui kesediaannya menyampaikan apa yang menjadi kehendak Tuhan bagi orang-orang yang dipimpinnya. Dalam tradisi Perjanjian Lama, seorang nabi bukan hanya menyampaikan rencana Tuhan bagi umatnya di masa depan, melainkan juga menyampaikan kritik atas polapola hidup yang tidak dikehendaki Allah, baik yang dilakukan oleh para pemimpin, tokoh agama maupun oleh masyarakat kebanyakan, sebagaimana yang dilakukan Amos dan Yesaya dan rekan-rekannya.

16 The Jakarta Post, "'If It's Good for the Country, Why Not?': Jokowi Justifies His Prabowo Pick,"
Ada tiga hal yang ingin ditekankan dari peran seorang pemimpin sebagai nabi. Pertama, pemimpin selalu menyuarakan kebenaran dan keadilan. Kedua, Pemimpin selalu menyuarakan yang baik yang sejalan dengan kehendak Allah bagi orang yang dipimpinnya. Ketiga, pemimpin mampu bersikap kritis terhadap perilaku-perilaku yang tidak sesuai dengan kehendak Allah, termasuk bersikap kritis terhadap dirinya sendiri. Untuk itu, meskipun seorang pemimpin bukanlah seorang nabi, dia bisa menjalankan peran seperti seorang nabi bila dia selalu menjalankan ketiga fungsi tersebut.

\section{Pasca Seratus Hari Kepemimpinan Presiden Joko Widodo}

Sikap Saul yang merangkul seluruh rakyat dapat kita temukan dalam tindakan Joko Widodo di periode kepemimpinannya yang kedua sebagai Presiden. Banyak orang yang memuji sikap Jokowi ketika dia mengangkat Prabowo Subianto sebagai menteri pertahanan. Rakyat Indonesia tahu bagaimana sikap keduanya sebagai calon presiden di pemilihan presiden tahun 2019. Koran the Jakarta Post mengomentari hal ini dengan beritanya: "'If it's good for the country, why not?': Jokowi justifies his Prabowo pick."16 Jokowi bukan hanya merangkul Prabowo, melainkan juga anggota-

The Jakarta Post, diakses 28 Februari 2020, https://www.thejakartapost.com/news/2019/10/25/if 
anggota dari partai-partai oposisi sebelumnya. Sikap Jokowi ini menunjukkan bahwa dia ingin merangkul semua rakyat, khususnya para pemimpin untuk bersama-sama membangun Indonesia. Jokowi tidak memedulikan persaingan dan sikap lawan politiknya di masa kampanye atau pemilihan presiden. Yang menjadi fokus Presiden Jokowi adalah pembangunan Indonesia ke depan. Sikap Jokowi ini sejalan dengan nilai kerendahan hati seorang pemimpin yang ditunjukkan Saul. Jokowi sejak jauhjauh hari juga sudah menunjukkan kerendahan hati dan sikap cinta damainya ketika dia mendorong Indonesia untuk menjadi penengah konflik Arab dan Iran. ${ }^{17}$ Upaya Indonesia ini dilihat sebagai momentum untuk mengupayakan damai keluar dari lingkungannya sendiri karena selama ini Indonesia dianggap lebih berkonsentrasi pada perdamaian di wilayah Asia Tenggara dan ASEAN. Presiden Joko Widodo melalui Menteri Luar Negeri menyampaikan surat kepada pemimpin Arab Saudi, Raja Salman, dan Presiden Iran, Hassan Rouhani

\footnotetext{
-its-good-for-the-country-why-not-jokowi-justifieshis-prabowo-pick.html.

${ }^{17}$ Lih. Agung Sedayu, "Jadi Penengah Konflik Iran Vs Arab Saudi, Indonesia Diapresiasi," Tempo, diedit terakhir 14 Januari 2016, diakses terakhir 28 Februari 2020, https://nasional.tempo.co/read/7360 67/jadi-penengah-konflik-iran-vs-arab-saudi-indone sia-diapresiasi.

${ }^{18}$ Lih. "Kontra Produktif di Balik Kenaikan Iuran BPJS Kesehatan," hukumonline.com, diedit terakhir
}

terkait dengan tawaran Indonesia menjadi penengah konflik Arab dan Iran.

Salah satu masalah yang dikedepankan sebagai kritik terhadap 100 hari pemerintahan Jokowi adalah masalah kesejahteraan masyarakat. Masalah ini dihubungkan dengan kenaikan tarif iuran Badan Penyelenggara Jaminan Sosial (BPJS) Kesehatan dan sejumlah kenaikan harga di awal tahun 2020. Sikap pemerintah menaikkan iuran BPJS membuat banyak warga masyarakat turun kelas karena kemampuan finansial yang terbatas dan juga bertambahnya tunggakan. ${ }^{18}$ Kenaikan ini dianggap akan mengurangi kesejahteraan masyarakat, sementara pelayanan kesehatan kepada masyarakat belum tentu menjadi lebih baik. ${ }^{19}$ Situasi ini memunculkan pertanyaan terkait dengan nilai tanggung jawab dari seorang pemimpin dalam upaya menyejahterakan rakyatnya. Presiden Jokowi tidak diragukan dalam hal pelaksanaan tanggung jawab yang berorientasi pada kewajiban ketimbang hak, tetapi bagaimana dengan tanggung jawab menyejahterakan rakyat. Jokowi akhir-akhir ini sering dikritik karena

31 Oktober 2019, diakses terakhir 28 Februari 2020, https://www.hukumonline.com/berita/baca/lt5dbafb e00f86a/kontra-produktif-di-balik-kenaikan-iuranbpjs-kesehatan/.

19 Lih. ara, "100 Hari Jokowi-Ma'ruf Menjabat, Beban Masyarakat Kian Berat," ekonomi, diakses terakhir 28 Februari 2020, https://www.cnn indonesia.com/ekonomi/20200127143231-532-469 095/100-hari-jokowi-maruf-menjabat-beban-masya rakat-kian-berat. 
cenderung memberikan perhatian besar kepada sektor industri ketimbang upaya meningkatkan kesejahteraan rakyat. Situasi ini juga dipengaruhi oleh masih lemahnya upaya untuk memacu pertumbuhan ekonomi. Omnibus Law yang akhir-akhir ini mendapat kritik banyak pihak juga dianggap tidak menjamin dapat meningkatkan pertumbuhan ekonomi.

Jokowi sendiri selalu mengatakan bahwa tidak ada target 100 hari di masa kepemimpinannya yang kedua ini, karena masih melanjutkan kepemimpinan yang pertama. Namun banyak pihak menyoroti munculnya masalah-masalah pasca 100 hari kepemimpinan Jokowi. Salah satu masalah serius lainnya yang disoroti pasca 100 hari pemerintahan Jokowi adalah masalah hukum dan HAM. ${ }^{20}$ Sorotan ini terutama berkaitan dengan meningkatnya radikalisme dan intoleransi, khususnya oleh kelompok mayoritas kepada minoritas. Pemerintah misalnya masih dikritik karena belum memberikan pelayanan perlindungan kepada penghayat kepercayaan meskipun keberadaan mereka telah diakui. ${ }^{21}$ Tindakan kelompok-kelompok intoleran terhadap kelompok agama minoritas dan lambatnya

${ }^{20}$ Lih. Kompas Cyber Media, "100 Hari JokowiMa'ruf, 9 Catatan YLBHI soal Buruknya Penegakan Hukum dan HAM Halaman all," KOMPAS.com, diakses terakhir 28 Februar 28, 2020, https://na sional.kompas.com/read/2020/01/30/05050001/100 -hari-jokowi-ma-ruf-9-catatan-ylbhi-soal-buruknyapenegakan-hukum-dan-ham. penanganan oleh pemerintah juga masih menjadi sorotan.

Persoalan intoleransi yang banyak menjadi perbincangan ketika tulisan ini dibuat adalah penolakan pembangunan atau renovasi Gereja Katolik Paroki Santo Joseph di Tanjung Balai Karimun oleh sekelompok orang yang mengatasnamakan Islam. Padahal pihak gereja telah mendapatkan IMB. Kelompok ini bahkan mengajukan gugatan kepemilikan IMB ini ke PTUN Batam. Menteri Agama, Fachrul Razi, malah memiliki pendapat berbeda dengan Jokowi dengan mengatakan bahwa tidak ada masalah intoleransi terkait Gereja Katolik di Karimun. Sikap Menteri Agama dalam menangani kasus ini memang berbeda dengan sikapnya dalam menyelesaikan masalah Masjid Al Hidayah di Minahasa. Di Minahasa Menteri Agama langsung mengeluarkan rekomendasi pembangunan, sementara Menteri Agama masih melihat persoalan di Karimun lebih pada persoalan IMB. Sikap menteri agama ini berbeda dengan sikap Presiden Jokowi yang meminta agar persoalan di Karimun segera di selesaikan. ${ }^{22}$ Situasi ini memunculkan titik terang ketika Presiden Jokowi me-

21 Ombudsman RI, "Pemerintah Belum Fasilitasi Kelompok Agama Yang Belum Diakui," diakses terakhir 28 Februari 2020, https://ombudsman .go.id:443/news/r/pemerintah-belum-fasilitasi-kelo mpok-agama-yang-belum-diakui.

22 "Soal Masjid Al Hidayah Minahasa, Kemenag Keluarkan Rekomendasi Pembangunan," Indopo litika.com, last modified February 1, 2020, diakses 
nugaskan Menko Polhukam dan Kapolri untuk menyelesaikan masalah pembangunan gereja di Karimun, karena menilai bahwa pemerintah daerah dianggal gagal dalam menyelesaikan persoalan tersebut. ${ }^{23}$ Yang menarik adalah Menteri Agama tidak dilibatkan dalam penyelesaian masalah ini, padahal masalah ini ada juga di ranah kementerian agama. Sikap Jokowi ini menurut saya menjadi cara Jokowi di dalam mengkritik para pembantunya yang dianggap tidak bisa bekerja sesuai dengan visi dan misi Jokowi.

Situasi intoleransi yang terjadi dan lambatnya sikap Presiden Jokowi terhadap persoalan ini memperlihatkan bahwa di satu sisi masih ada perhatian Jokowi terhadap upaya menghadirkan rasa aman dan damai bagi rakyat yang dipimpinnya, tetapi di sisi lain sikap ini masih belum ditunjukkan dengan cepat ketika persoalan sudah bergulir dan menghangat di masyarakat. Presiden Jokowi terlalu memberikan kepercayaan yang besar kepada para pembantunya untuk menyelesaikan masalah

28 Februari 2020, https://indopolitika.com/soalmusala-al-hidayah-minahasa-kemenag-keluarkan-re komendasi-pembangunan/; "Menteri Agama Beda dengan Jokowi Soal Kasus Gereja di Kepri," nasional, diakses 28 Februari 2020, https://www .cnnindonesia.com/nasional/20200219022209-20-4 75924/menteri-agama-beda-dengan-jokowi-soal-ka sus-gereja-di-kepri; Kompas Cyber Media, "Keme nag Sebut Polemik Gereja di Karimun Bukan Masalah Intoleransi," KOMPAS.com, diakses 28 Februari 2020, https://nasional.kompas.com/read/ 2020/02/18/18475001/kemenag-sebut-polemik-gere yang ada, sementara para pembantunya belum bisa menyelesaikan masalah itu sebagaimana yang diharapkan Jokowi. Akibatnya pemerintah secara keseluruhan dianggap cenderung membiarkan perilakuperilaku intoleransi terjadi atau lambat dalam menyelesaikan masalah-masalah terkait intoleransi.

Jokowi dan para pembantunya perlu belajar dari sikap Saul dalam mengupayakan rasa aman dan damai kepada penduduk Yabesh-Gilead. Setelah mendengar persoalan yang dialami penduduk Yabesh Gilead, Saul segera mengumpulkan pasukan yang dimilikinya dan mengirim pesan bahwa dia akan datang untuk membebaskan mereka. Sikap tanggap dan cepat dalam menyelesaikan masalah-masalah intoleransi masih belum dimiliki pemerintah Jokowi. Pembantu-pembantu Jokowi di daerahdaerah juga cenderung membiarkan perilaku intoleransi terhadap kelompok minoritas berlangsung berlarut-larut tanpa ada upaya cepat menyelesaikannya. Masalah GKI Yasmin yang sudah terjadi bertahun-

ja-di-karimun-bukan-masalah-intoleransi; Kadek Melda L, "Soal Penolakan Renovasi Gereja di Kepri, Kemenag: Tak Ada Masalah Intoleransi," detiknews, diakses 28 Februari 2020, https://news.detik. com/berita/d-4904432/soal-penolakan-renovasi-ge reja-di-kepri-kemenag-tak-ada-masalah-intoleransi. ${ }^{23}$ BeritaSatu.com, "Pemda Tidak Mampu, Jokowi Perintahkan Menko Polhukam dan Kapolri Turun Tangan," beritasatu.com, diakses terakhir 28 Februari 2020, https://www.beritasatu.com/nasional /600033/pemda-tidak-mampu-jokowi-perintahkanmenko-polhukam-dan-kapolri-turun-tangan. 
tahun juga masih belum ada penyelesaiannya. Padahal ibadahnya berlangsung setiap minggu di depan istana presiden. Untuk itu keteladanan penting dihidupi oleh Jokowi dan para pemimpin di Indonesia. Tanggung jawab seorang pemimpin adalah menghadirkan rasa aman dan damai dalam kehidupan bersama. Jika ada kelompok masyarakat yang merasa terancam atau ditekan oleh pihak yang lain, maka tugas pemimpin adalah membebaskan kelompok masyarakat itu dari tekanan atau ketidakamanan yang mereka alami.

Sikap Saul yang memilih jalan damai ketika merespons provokasi agar dia membalas sikap tidak baik yang ditunjukkan kepadanya patut menjadi model dalam merespons aksi-aksi intoleran dan kekerasan yang ada. Seorang pemimpin juga harus memiliki komitmen untuk mengajarkan orang-orang yang dipimpinnya untuk tidak menjadikan kekerasan sebagai jalan keluar dalam menyelesaikan persoalan yang ada, bahkan untuk merespons kekerasan yang mereka terima. Kekerasan akan selalu menghadirkan rasa tidak aman dan ketidaktenangan hidup, karena itu kekerasan tidak boleh menjadi bagian dari cara hidup bersama dalam masyarakat. Inilah teladan penting ditunjukkan oleh Saul.

\section{KESIMPULAN}

Berkaca dari peristiwa-peristiwa yang terjadi di seputar penobatan Saul sebagai raja, 100 hari periode kedua pemerintahan Presiden Joko Widodo pada satu sisi cukup diapresiasi terutama dalam hal upaya mewujudkan damai sejahtera melalui manuver merangkul pihak-pihak yang selama ini berseberangan. Hal itu membuktikan bahwa Presiden Jokowi tidak menggunakan politik balas dendam, namun sebaliknya berupaya mendahulukan kesatuan bangsa. Namun demikian, lambatnya penanganan masalah hukum dan HAM menjadi catatan tersendiri. Masyarakat, khususnya kaum minoritas, yang mengharapkan seorang pemimpin yang menghadirkan keadilan bagi semua tampaknya harus bersabar menunggu ketegasan Presiden Jokowi untuk mewujudkannya.

\section{DAFTAR PUSTAKA}

ara. "100 Hari Jokowi-Ma'ruf Menjabat, Beban Masyarakat Kian Berat." ekonomi. Accessed February 28, 2020. https://www.cnnindonesia. com/ekonomi/20200127143231-53 2-469095/100-hari-jokowi-marufmenjabat-beban-masyarakat-kianberat.

BeritaSatu.com. "Pemda Tidak Mampu, Jokowi Perintahkan Menko Polhukam dan Kapolri Turun Tangan." beritasatu.com. Accessed February 28, 2020. https://www.beritasatu. com/nasional/600033/pemda-tidakmampu-jokowi-perintahkan- 
menko-polhukam-dan-kapolriturun-tangan.

Blenkinsopp, Joseph. A History of Prophecy in Israel. Lousville, Kentucky: Westminster John Knox Press, 1996.

Brueggemann, Walter. First and Second Samuel. Lousville, Kentucky: Westminster John Knox Press, 2012.

Chapman, Stephen B. 1 Samuel as Christian Scripture: A Theological Commentary. Wm. B. Eerdmans Publishing, 2016.

Clinton, Boruch. The Royal Prophet - And Other Thoughtful Essays on the Book of Samuel. Toronto: Marbitz Media, 2014.

Davies, Philip R. "Saul, Hero Dan Villain." In Remembering Biblical Figures in the Late Persian and Early Hellenistic Periods, edited by Diana V. Edelman and Ehud Ben Zvi, 131-140. Oxford: Oxford University Press, 2013.

Farber, Zev. Images of Joshua in the Bible and Their Reception. Berlin: Walter de Gruyter GmbH, 2016.

Fleming, Daniel. The Legacy of Israel in Judah's Bible: History, Politics, and the Reinscribing of Tradition. New York: Cambridge University Press, 2012.

George, Mark K. "Yhwh's Own Heart." The Catholic Biblical Quarterly 64, no. 3 (2002): 442-459.

Gunn, David M. Fate of King Saul: An Interpretation of a Biblical Story. Sheffield: JSOT Press, 1989.

Ishida, Tomoo. History and Historical Writing in Ancient Israel: Studies in Biblical Historiography. Leiden: Brill, 1999.
L, Kadek Melda. "Soal Penolakan Renovasi Gereja di Kepri, Kemenag: Tak Ada Masalah Intoleransi." detiknews. Accessed February 28, 2020. https://news.detik.com/berita/d4904432/soal-penolakan-renovasigereja-di-kepri-kemenag-tak-adamasalah-intoleransi.

Leclerc, Thomas L. Introduction to the Prophets: Their Stories, Sayings and Scrolls. New Jersey: Paulist Press, 2007.

Lumban Gaol, Hotman J. "Memberdayakan Ekonomi Jemaat Lewat Credit Union." Reformata, 2012.

Media, Kompas Cyber. "100 Hari JokowiMa'ruf, 9 Catatan YLBHI soal Buruknya Penegakan Hukum dan HAM Halaman all." KOMPAS.com. Accessed February 28, 2020. https://nasional.kompas.com/read/2 020/01/30/05050001/100-harijokowi-ma-ruf-9-catatan-ylbhisoal-buruknya-penegakan-hukumdan-ham.

. "Kemenag Sebut Polemik Gereja di Karimun Bukan Masalah Intoleransi." KOMPAS.com. Accessed February 28, 2020. https: //nasional.kompas.com/read/2020/0 2/18/18475001/kemenag-sebutpolemik-gereja-di-karimun-bukanmasalah-intoleransi.

Merkur, Dan. "Biblical Terrorism." In $A$ Cry Instead of Justice: The Bible and Cultures of Violence in Psychological Perspective, edited by Dereck Daschke and D. Andrew Kille, 55-79. New York: $\mathrm{T} \& \mathrm{~T}$ Clark, 2010.

Miller, Geoffrey P. The Ways of a King: Legal and Political Ideas in the Bible. Vandenhoeck \& Ruprecht, 2011. 
Polzin, Robert. Samuel and the Deuteronomist: A Literary Study of the Deuteronomic History Part Two: 1 Samuel. Bloomington \& Indianapolis: Indiana University Press, 1993.

Post, The Jakarta. "If It's Good for the Country, Why Not?': Jokowi Justifies His Prabowo Pick." The Jakarta Post. Accessed February 28, 2020. https://www.thejakarta post.com/news/2019/10/25/if-itsgood-for-the-country-why-notjokowi-justifies-his-prabowopick.html.

RI, Ombudsman. "Pemerintah Belum Fasilitasi Kelompok Agama Yang Belum Diakui." Accessed February 28, 2020. https://ombudsman.go .id:443/news/r/pemerintah-belumfasilitasi-kelompok-agama-yangbelum-diakui.

Sedayu, Agung. "Jadi Penengah Konflik Iran Vs Arab Saudi, Indonesia Diapresiasi." Tempo. Last modified January 14, 2016. Accessed February 28, 2020. https://nasional. tempo.co/read/736067/jadipenengah-konflik-iran-vs-arabsaudi-indonesia-diapresiasi.

Setio, Robert. "Penguasa, Tuhan, Dan Rakyat: Membaca Apokalips Daniel 7 Sebagai Subversi." Gema Teologika: Jurnal Teologi Kontekstual dan Filsafat Keilahian 4, no. 2 (October 16, 2019): 211228.
Tarmedi, P. A. Didi. "Analisis Naratif: Sebuah Metode Kristiani Hermeneutika Kitab Suci." MELINTAS 29, no. 3 (2013): 331-360.

Wijaya, Yahya. Kesalehan pasar: kajian teologis terhadap isu-isu ekonomi dan bisnis di Indonesia. Jakarta: Grafika Kreasindo, 2010.

Wright, Jacob L. David, King of Israel, and Caleb in Biblical Memory. New York: Cambridge University Press, 2014.

"Kontra Produktif di Balik Kenaikan Iuran BPJS Kesehatan." hukumonline. com. Last modified October 31, 2019. Accessed February 28, 2020. https://www.hukumonline.com/beri ta/baca/lt5dbafbe00f86a/kontraproduktif-di-balik-kenaikan-iuranbpjs-kesehatan/.

"Menteri Agama Beda dengan Jokowi Soal Kasus Gereja di Kepri." nasional. Accessed February 28, 2020. https://www.cnnindonesia.com/nasi onal/20200219022209-20475924/menteri-agama-bedadengan-jokowi-soal-kasus-gerejadi-kepri.

"Soal Masjid Al Hidayah Minahasa, Kemenag Keluarkan Rekomendasi Pembangunan." Indopolitika.com. Last modified February 1, 2020. Accessed February 28, 2020. https://indopolitika.com/soalmusala-al-hidayah-minahasakemenag-keluarkan-rekomendasipembangunan/. 